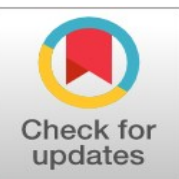

\title{
Teachers' soft skills proficiency level and school performance of selected schools in Sultan Kudarat Division
}

\author{
Hector L. Lavilles Jr ${ }^{1 *}$, Ava Clare Marie 0. Robles ${ }^{2}$ \\ 1, 2 Department of Education, Mindanao State University, Fatima, Philippines
}

\author{
Key Words \\ Soft skills \\ Soft skills \\ Proficiency level \\ School performance \\ Sultan Kudarat
}

Received: 22 May 2016

Accepted: 25 June 2016

Published: 27 February 2017

\begin{abstract}
Twenty-first-century education requires wide-ranging knowledge and skills of teachers critically important to school's success. The value of soft skills becomes a trend. However, there has not been any study conducted on the soft skills proficiency level of the teachers and school performance in Sultan Kudarat. For this reason, the study aimed to determine teachers' soft skills proficiency level and school performance of selected schools in the Division of Sultan Kudarat. It also provided discussions on the relationship between teachers' soft skills proficiency level and school performance. A descriptive-correlation research method was used in this study: a descriptive research study aimed to determine the teachers' soft skills proficiency level and their school performance. Moreover, a correlational analysis was done to determine a significant relationship between teachers' soft skills proficiency level and their school performance. The researcher used a modified questionnaire, interview, and documentary analysis of the records taken from each school. The primary respondents of this study were the one hundred sixteen (116) teachers of Esperanza Central School, Kalawag Central School, and Tamang Central School in the Division of Sultan Kudarat S.Y 2015-2016. The results showed that teachers have high soft skills proficiency level $(M=4.08)$. Schools also showed differences in the level of performance for three (3) years. The results also revealed a significant relationship between teachers' soft skills proficiency level and school performance. This indicates that high-level of soft skills proficiency tend to improve the school performance. The findings study may serve as a basis for teachers and administrators to efficiently integrate soft skills to support and enhance school performance. The study may also contribute to the growing body of knowledge about the relationship of teachers' soft skills to school performance.
\end{abstract}

(C)2017 The Author(s). Published by TAF Publishing.

\section{INTRODUCTION}

Educational sectors have become more complex and competitive to adapt to the changes in the society. Likewise, human resources are considered significant in organizational performance and in achieving success. The standards for hiring 21st century teachers have become even more dynamic due to the demands of the educational system to evolve and increase their level of performance.

In the Philippines, the Department of Education strongly implements its goals and objectives by evaluating the performance of the schools annually based on the given criteria. These criteria include national achievement rate, enrollment rate, drop-out rate, cohort survival rate and repetition rate (Maligalig et al., 2010). The teachers are required

\footnotetext{
${ }^{*}$ Corresponding author: Hector L. Lavilles Jr

${ }^{\dagger}$ Email: hectorlavillesjr@gmail.com
} 
to keep abreast with updated knowledge and utilize various skills and strategies in giving instructions to have an effective learning environment and contribute to their school performance. However, the roles of the teachers do not only focus on delivering lessons to the pupils. Teachers also need soft skills, aside from the technical skills for them to be effective in the classroom and contribute to uplift the performance of the school. For this, soft skills of the teachers build a relationship with the school performance.

Studies were conducted to determine the significant effect of soft skills on various organizations, and these led to different outcomes. Nevertheless, in the country, supervisors viewed soft skills as equally important as hard skills in running the organization (Marcial, 2012). The Department of Education emphasized that these skills were significant on the academic achievement of the learners and school performance.

Despite the trend of soft skills in various organizations, there are still some teachers who are unfamiliar with the value of soft skills in the work field because of the lack of understanding and failure to integrate while delivering instructions. Teachers need to overcome these hindrances and meet the standards of the 21st century society by exercising their soft skills proficiently in teaching the learners and improving the school performance.

With this gathered information, the researcher attempted to go to a deeper study by determining the soft skills proficiency level of the teachers and its relationship with the school performance. Also, this study determined the extent of the performance of the selected schools.

\section{Objectives}

The study aimed to find out the soft skills proficiency level of the teachers and the school performance of selected schools in the Division of Sultan Kudarat.

Specifically, the study sought answers to the following questions:

1. What is the soft skills proficiency level of the teachers in terms of:

1.1 Communication skills;

1.2 Teamwork;

1.3 Critical thinking;

1.4 Ethics; and

1.5 Leadership skills?

2. What is the extent of their school performance relative to:

2.1 National Achievement Rate;

2.2 Drop-out Rate; and

2.3 Completion Rate?

3. Is there a significant relationship between the soft skills proficiency level of the teachers and their school performance?

The researcher considered possible explanations for the findings and contextualized these with the broader field of school performance.

\section{REVIEW OF RELATED LITERATURE Soft Skills}

Teachers are facing various modifications in their functions and responsibilities in the society. Thus, it is important for the teachers to possess soft skills to achieve success and cope with the changes in the organization (Lee and Tien-Tse, 2011). Hart and Mark (2003) believed that the application of soft skills in the workplace could produce sustainable development. Marcial (2012) highlighted that soft skills are the personal attributes that influ- 
ence individual's interpersonal relationships, job performance, and career outlook. Further, these skills help mold the personality and professionalism of managers in the working environment. Bhatnagar (2011) identified that soft skills serve as one of the primary qualifications for getting a job in today's economy.

Jamison (2010) posited that the integration of soft skills is essential for the organization to prosper and continuously achieve its goals. Soft skills formation of the workers plays a part to the success of the organization (Majid et al., 2012; Nikitina and Fumitaka, 2012). Bhatnagar (2011) recognized that employees with poor soft skills have disadvantages in achieving both personal and professional success.

Marcial (2012) stressed that gender, civil status, educational attainment and employment status do not affect the soft skills of the workers. He also found that soft skills help shape the personality and working behavior of the employees. However, employees were always recommended to equate soft skills with technical expertise to be efficient in performing their jobs.

Robles (2012) identified soft skills as the personal qualities of a person such as professionalism, integrity, responsibility and flexibility that are significant in the workplace. Moreover, Deepa and Manisha (2013) added that soft skills comprise of various interpersonal skills of an individual that are necessary for creating a relationship with others. These skills include leadership skills, teamwork, emotional aptitude and ability to deal with stress.

Ward and Dorothy (2014) emphasized that soft skill proficiency plays a very significant role in career-life and must not be overlooked by the employees. Any organization can effectively serve the clienteles if workers strengthen these skills and mindfully integrate into daily services.

The school system values the soft skills of the teachers. These skills are pivotal in creating a relationship with the learners to strengthen their emotional competence and advance their academic achievement (Majid et al., 2010; Toyama, 2014). Ngang et al. (2015) identified that soft skills help the teachers perform their functions successfully amidst the job difficulty. Bhatnagar (2011) also remarked that soft skills proficiency strengthens the confidence of the teachers.

Teachers utilize various approaches to teaching the learners. The extent of knowledge of the subject matter enhances the level of students' achievement (Liu and Dong, 2016; Metzler and Ludger, 2012; Tarmuchi et al., 2015). Kunter et al. (2013) added that the competence of the teachers such as knowledge of the subject matter, instructional competence and enthusiasm has positive effects on students' learning outcomes.

Farmer et al. (2011) mentioned that educators have the crucial role of perceiving the child as a whole about the functions of the society in which he is an integral part. Thus, teachers' effectiveness has a significant effect on the growth of the learners (Kane et al., 2011).

Teachers' skills such as cognitive and soft skills help shape the behavior of the students and contribute to the efficiency in delivering teaching-learning process (DiPrete and Jennifer, 2012; Harn, 2015; Jacolbia, 2015). DiPrete and Jennifer (2012) added that teachers who perform well in developing behavioral skills also contribute to the improvement of the academic level of the learners. Denham et al. (2013) emphasized that the emotional being of the pupils can be developed through providing various activities for them to experience. 


\section{Communication Skills}

Conrad and Robert (2011) highlighted that good communication skills are significant factors in increasing performance and relationship in the workplace. Further, Tang et al. (2013) emphasized that the way the administrators converse with their employees determines the level of trust they received from them.

In the field of education, Lee and Tien-Tse (2011) posited that communication skills are one of the soft skills that must be acquired by the teachers. They believed that teachers could improve their roles by sharing insights through various forms of communications and learn from them. The communication skills of the teachers are salient features in dealing with the learners and in their academic advancement (Majid et al., 2010). Further, Keller et al. (2014) highlighted that the enthusiasm of the teachers boosts the interest of the pupils and increases the level of motivation towards the learning process.

Conrad and Robert (2011) claimed that teachers perceived communication competence as essential in the organization. The skills such as using information technology, writing business correspondence, creating group synergy and demonstrating respect were given greater importance by business leaders and teachers. These skills help the teachers in promoting the affective domain of the learners, especially in creating bond necessary for emotional development (Majid et al., 2010; Toyama, 2014).

Bhatnagar (2011) mentioned that communication is one of the most important soft skills for teachers. Through communication skills, teachers can persuade, train, present, inspire, and teach the learners. Thus, Rao (2010) remarked that communication skill is the core of soft skills. Without this skill, other soft skills become irrelevant.

Training (2012) stressed that non-verbal communication such as tone of voice and nonverbal gestures matters even more than spoken words. He found that people believed non-verbal communication compared to verbal communication when two are contradictory during face-to-face interaction. Similarly, Dede (2010) posited that teachers should be skillful in dealing with complex communication that requires vast amounts of verbal and non-verbal information. In this way, they can improvise answers and manage unpredictable and chaotic classroom discussion.

In the Philippines, Marcial (2012) claimed that administrators are good communicators. They practice open communication and demonstrate fairness in the workplace. Further, they accept limitations and consider the constructive criticisms from others intended to enhance their performance.

Communication skills play a vital role in every function and part of the organization. Every staff is encouraged to have communication competence to carry out their roles effectively. Organizations must develop programs that enhance the communication skills of the employees for all the organization practices instead for particular projects (Conrad and Robert, 2011).

Amini et al. (2010) highlighted that communication skills positively influence educational performance. Thus, the school should include training courses that will boost the communication skills of the teachers for effective teaching.

\section{Critical Thinking Skills}

Dixon et al. (2010) found that critical thinking is one of the most sought skills by the managers in the organization. He also added that critical thinking is vital in coping with complicated situations in the workplace. Critical thinking includes various skills such as curiosity, problem definition, scrutinizing evidence, open-mindedness, and analytical thinking (Ghaemi and Reza, 2011). Critical thinking demands cognitive skills and dispositions which can be represented as attitudes which include open and fair-mindedness, inquisi- 
tiveness, flexibility, ability to seek for reasons, desire to be well-informed and willingness to entertain diverse idea (Lai, 2011).

In this era where too much information is pouring, the competence to think critically gained greater importance (Birjandi and Marzieh, 2010). Lai (2011) identified that critical thinking comprises of various components such as analyzing arguments, making inferences through deductive and inductive reasoning, judging and decision-making. Ghaemi and Reza (2011) added that critical thinking relates to philosophical and educational perspectives. Each perspective indicates an essential role in social and education life.

In addition, James (2015) introduced five variables under critical thinking skills like inference, assumption, deduction, interpretation and arguments. Critical thinking requires considerable efforts to scrutinize any idea in the light of supporting facts and evidence that make individuals decide what to believe or do under reasonable terms (Fisher, 2011).

Ghaemi and Reza (2011) posited that critical thinking is significant to teachers' success. Thus, teachers should embrace the components of critical thinking skills in the teaching profession due to its contribution towards teaching accomplishments.

Birjandi and Marzieh (2010) found that critical thinking skills showed a positive relationship with teachers' success. The study implied that education must accommodate critical thinking as an important aspect of the teachers and address the need to intensify their critical thinking ability. Thus, Ghaemi and Reza (2011) stressed that all educational levels should offer learning areas that support and develop critical thinking skills.

Critical thinking is significant to learning outcomes such as metacognition, motivation, collaboration and creativity (Lai, 2011). James (2015) found that males have higher inference and interpretation skills than females. On the other hand, females have shown more argument skills than men.

\section{Teamwork}

Teamwork comprises of various skills such as arriving on time promptly, sharing opinion and knowledge, considering the suggestion of others, showing respect to other team members and providing help to others (Lingard, 2010a).

Teamwork is significant in the workplace (Lingard, 2010a; Strom and Robert, 2011). Ngang at al. (2015) added that teamwork skills are the most required competency in the organization. Deepa and Manisha (2013) emphasized that any organization needs a series of interaction among its workers to carry out a certain task. These interactions create a robust and healthy atmosphere required to achieve the goals and objectives.

Lingard (2010b) stressed that teamwork could be assessed through various strategies such as independent observation, evaluating individual contributions and peer review. He also added that teamwork needs to be understood clearly before imparting the skills to others.

In the field of education, Main (2010) found that teachers' isolation is one of the hurdles that hinder the achievement of the goals and objectives of the school. Isolation with others prevents teachers from exchanging ideas with others that are vital in widening their skills and performing their duties and responsibilities successfully. Thus, he identified that collaboration with other teachers is a key strategy for better job performance.

However, Crutchfield and Kimberly (2014) highlighted those team members who are identified as free-riders and rely on high performing team members are the pitfalls of teamwork in the organization. This system creates a disproportionate burden on active and dynamic members.

Lee and Tien-Tse (2011) established that effective teamwork needs each member to listen to one another and refrain from making early conclusions. Dixon et al. (2010) added 
that the real essence of teamwork requires sharing of responsibility and commitment of every member to achieve the goals of the group.

In the classroom setting, Maldonado and Elizabeth (2011) posited that teamwork creates strong rapport between learners and teachers and promotes the positive development of the students through improved academic skills and diminished behavioral problems.

\section{Ethics}

Koonme et al. (2010) revealed that ethics positively influence the quality of work life and employee job-related outcomes such as job satisfaction, organizational commitment, etc. Thus, ethics should be institutionalized to various sectors.

Kim and Minsoo (2013) also recognized that the moral competence of the leaders positively influences the subordinates in performing their tasks. The way the workers behave in the organization depends on the moral proficiency of the leaders. Narvaez (2001) identified seven skills necessary for ethical sensitivity. It includes reading and conveying emotions, considering one's opinion, concern for others, responding to diversity, avoidance to biases, gathering interpretations and determining consequences of the actions.

Further, Langlois and Claire (2010) recognized that increasing the ethics of an individual is significant in becoming an effective leader. School administrators believed that possessing ethical and moral skills is important in coping with the complexities of the job (Ngang et al., 2015).

Care ethics that include listening, dialogue, critical thinking, reflective response, and making deep connections are significant in establishing and maintaining trust between students and teachers (Noddings, 2010). In addition, Boon (2011) highlighted the need for teachers to undergo training courses which include philosophy units. This approach supports teachers' quality by providing methods and strategies to explore and teach complex ethical issues.

Kuusisto et al. (2012) posited that ethical sensitivity opens opportunities for cooperation in the school system. The way teachers understand, and express emotions is essential in creating a caring relationship with the students.

Ngang et al. (2015) highlighted that the poor ethical skills of the teachers prevent them from achieving the goals of the school and from being a model to the students. . Ethics play a vital role in shaping individual's personality towards excellence.

Shapira-Lishchinsky (2011) identified the different ethical dilemmas in the school. These dilemmas involve clashing with rules, standards, norms and opposing responses. Thus, educational programs must be developed based on teachers' critical incidents.

The ethics of teaching involve a commitment to the students and the profession. Teachers were vested by the public with trust and responsibility to deliver the highest service. Thus, the educators are encouraged to raise the professional standards and exercise the right to professional judgment (Strike, 2015).

\section{Leadership Skills}

Moreover, collaborative effort and leadership in school significantly increase students' learning by supporting the goal of the school towards academic achievement (Hallinger and Ronald, 2010). Ibrahim and Shaikah (2012) added that leadership skills contribute to the efficiency of the school heads in performing their roles and functions.

Puccio et al. (2010) highlighted that leadership skills comprise of various criteria that are beneficial to the organization. Leaders create a connection with the subordinates. They also understand the diversity in the workplace and empower the potentials of oth- 
ers through the creative process. Similarly, Bhatnagar (2011) emphasized that leadership skills involve motivating and assisting others to reach their innate capacities and devise visions for the organization.

Marques (2013) stressed that future leaders should strengthen their leadership skills to be efficient in the organization. He also identified motivation, empathy, self-awareness and regulation as factors of effective leadership. Tang et al, (2013) highlighted that the leadership skills of administrators help them gain support and trust from their subordinates.

Leadership skills include improving group performance through the use of a creative process, empowering the talent, intelligence, and creativity of others, turning challenging opportunities to remarkable successes, experimenting and learning from failures and responding to change and proactively drive change (Puccio et al., 2010).

Balcar (2014) found that these soft skills contribute to the level of income of the employees. Workers who possess strong soft skills will likely receive a higher salary in the organization. Gould and Deborah (2012) added that strengthening the soft skills of the workforce leads to higher remuneration and advances the level of authority and responsibility.

Various organizations formulate incentive system in the form of promotion and higher remuneration for employees who possess both technical and soft skills. These skills allow the workforce to adapt when work becomes flexible in the organization (Prasad and Hien, 2011; Prasad and Hien, 2013).

Helterbran (2010) stressed that teachers have always been leaders. However, public schools provide a minimum opportunity to promote and intensify teacher leadership in the work field. Teacher leadership is becoming more significant today. Leadership requires vision in education and efforts to achieve and accomplish (Ludlow, 2011).

Adeyemi (2010) found that democratic leadership style is the most widely practiced leadership style of the principals. Nevertheless, teachers' job performance was higher under school heads practicing autocratic leadership style. Further, the application of laissezfaire leadership style was discouraged among school heads as it could not improve teachers' performance. Khasawneh et al. (2012) highlighted that transformational leadership significantly influences organizational commitment. Adeyemi (2010) recommended that school principals should integrate various leadership styles especially autocratic and democratic to advance the job performance among teachers. Hulpia and Geert (2010) stressed that teachers were committed to the task if the principals were accessible, efficient in facing problems, and frequently monitor teachers' daily performance. Effective school leadership supports students' achievement, especially when paired with healthy school atmosphere that encourages cooperation. Seashore et al. (2010) posited that leadership skills positively influence student achievement. They also suggested that both shared and instructional leadership supplements to the improvement of the school. Kano (2012) found that dynamic school leadership is one of the variables of high-performing schools. Leadership skills help academic performance and is a significant factor to the success of the school system.

\section{School Performance}

Sarrico et al. (2012) found that school performance evaluations are not entirely equipped to assess the achievements of the school. Most schools utilize the test result completion and progression rates of the learners as indicators of the school performance. Thus, Kano (2012) suggested that school performance should also include other indicators like the skills of the learners necessary for survival. Jackson and Fred (2010) identified academic 
excellence, developmental responsiveness, social equity and organizational commitment as variables of performance indicators. He also found that all four variables showed significance with students' achievement. In the Philippines, the Department of Education used the National Achievement Rate, enrollment rate, dropout rate, cohort survival rate, completion rate and repetition rate of the school as variables for school performance (Maligalig et al., 2010). Harris et al. (2010) identified that teaching skills and intelligence are significant factors towards teachers' productivity and school success. Romano et al. (2010) added that the socio-emotional behaviors of the learners influence their academic achievement and serve as a gauge for determining school success. Maligalig et al. (2010) found that the declining of key indicators of educational outcomes becomes a trend in the country. Thus, the Department of Education should formulate and implement various intervention programs to stop the trend and encourage every household to send their children to schools.

\section{Achievement Rate}

In the Philippines, National Achievement rate refers to the degree of performance of the learners in various subject areas in different levels of education (Maligalig et al., 2010). Ouko (2015) stressed that learning experiences encountered before formal education serve as a strong foundation for the academic achievement and progression. Thus, educational systems are advised to provide the right age for learners before enrolling in the curriculum. Saifi and Tariq (2011) highlighted that socio-economic status which presents family's economic and social position relative to others based on income, education and occupation is a factor of students' achievement. They found that educated parents have higher academic achievement than uneducated parents. Further, the economic status of the family leads to better performance of the learners in school. Meanwhile, the seating arrangement in class is also significant to their performance. Pupils who are sitting in front rows were more motivated and confident to learn and participate. Thus, the stability of socio-economic status brings comfort and positive attitude which leads to higher academic achievement of the learners.

Meanwhile, Adeyemi (2010) found that teachers are significant in students' achievement. He also laid importance on the value of workshops and training of teachers to be knowledgeable about various teaching styles that will lead to a higher attainment of the pupils. Further, he concluded that the government should eagerly support and encourage teachers to continuously search for knowledge to upgrade their qualifications that make them productive and proficient in various areas. Teachers' self-efficacy and the type of school attended were significant to learners' achievement in literacy and numeracy (Ouko, 2015). He also recommended parents and teachers to provide quality pre-education learning experiences to be equipped with skills needed to cope with the standards of formal education. Adeyemi (2010) added that teachers' experience and educational qualifications are essential to pupils' achievement. Romano et al. (2010) posited that socio-emotional behaviors of the learners influence their academic achievement and serve as a gauge in determining school's success. Thus, Kunter et al. (2013) highlighted that teachers' competence such as knowledge of the subject matter, enthusiasm, and instructional skills help deal with the behaviors of the students and have positive effects on students' learning outcomes. However, Pandiello et al. (2014) found that grade retention has a negative impact on educational outcomes.

Abd Hamid et al. (2012) mentioned that professionalism is significant in supervising instructional activities that are vital to improving academic achievement. Thus, Taylor et al. (2010) concluded that poor teaching skills hinder the learners from developing 
their fullest potentials. Also, Kythreotis et al. (2010) highlighted that principal's human resource leadership style and learning culture inside the classroom influence students' achievement.

\section{Drop-out Rate}

Maligalig et al. (2010) posited that drop-out rates are the percentage of learners who exited the school during a school year for any reasons as well as pupils who enrolled the previous year but failed to enroll in the next school year. Sabates et al. (2011) highlighted that the dropout rate of the students is not a result but a process that involves various causes. Hence, teachers need to be proactive in dealing with the problem to intervene the situation successfully. Further, Yamauchi and Yanyan (2011) found that the intervention programs conducted by the teachers improved the national achievement test scores of the learners. Yi et al. (2012) stressed that despite the efforts of the government to reduce the level of drop-out rates in school, it is not enough to solve the problem. Drop-out related factors can be related to both interpersonal and institutional reasons. In addition, Breier (2010) found that students' retention rate in school is not isolated to a single factor. Dropout rates relate to low students' performance and socio-economic status. In the country, the socio-economic status serves as strong predictors for the participation and attendance of the learners in the school. To address this situation, the Department of Education implemented various intervention programs such as Instructional Management by Parents, Community, and Teachers which provide self-learning materials to high risks pupils (Maligalig et al., 2010).

Further, based on the study of Maligalig et al. (2010) boys are primarily prone to leaving the school compared to the girls. This result was due to lack of motivation and negative attitude towards the school. Thus, the Department of Education implements a Dropout Intervention Program that includes targeted interventions such as Instructional Management by parents, community, and teachers as well as Out-Of-School Approach. Chapman et al. (2011) also identified that males had higher drop-out rates compared to females. He added that students living in low-income families are also prone to dropping out of schools. Yi et al. (2012) also identified that drop-out rates were higher for students that came from low-income families. Age also influences students from leaving the school. They found that older students are more prone to leave the school.

\section{Completion Rate}

Maligalig et al. (2010) stressed that completion rate is the percentage of students who enrolled at the beginning grade and reached the final grade based on the required number of years of study. Chapman et al. (2011) found that gender is a significant factor why learners leave the school without completing all educational levels. He identified that males had higher chances of leaving the school compared to females. The socio-economic status also plays a strong indicator for the completion rate of the students. Breier (2010) identified skills, financial resources, educational background, and dispositions influence students' retention rate in school. Many pupils left before completing the required educational levels because they were too poor to remain in the school.

Migosi et al. (2012) stressed that although there are convincing factors that encourage higher participation of the pupils, the hindering factors are also overwhelming. Education requires concerted efforts of education providers to overcome these difficulties. Education is a strong factor of the future and present situation and must be delivered to all kinds of learners regardless of gender, age, and socio-economic status. 


\section{METHODOLOGY}

A questionnaire was utilized to gather the needed data of this study. The questionnaire covered the soft skills proficiency level of the teachers and was adopted and modified from Ngang et al. (2015) as an essential tool in assessing the soft skills proficiency level of the teachers. The test was subdivided into five sub-components: Communication Skills, Critical Thinking Skills, Teamwork, Ethics, and Leadership Skills. The other tool was an interview guide. The questionnaire was given to the two (2) academic heads of different schools and the Education Program Supervisor of the Division of General Santos City for validation. This instrument was checked and evaluated, and revisions were made according to the suggestions of the evaluators and the approval of his thesis adviser and the members of the panel of examiners. The Questionnaire was also pilot-tested to an adjacent school to determine its reliability level. Meanwhile, the extent of school performance regarding the National Achievement Rate, Drop-out Rate, and Completion Rate was taken from the records of each school. Interviews were carried out soon after details were received. Once the researcher completed the data collection, he utilized weighted mean to identify the proficiency level of teachers' soft skills. A Five-point Likert scale was used to interpret the results of the study. The researcher also conducted a documentary analysis after taking the records kept in each school to determine the extent of school performance. Finally, the researcher used multiple regression to determine if there is a significant relationship between teachers' soft skill proficiency level and the school performance.

\section{Respondents}

The total respondents of the study were the one hundred sixteen (116) teachers of Esperanza Central School (32), Kalawag Central School (56) and Tamnag Central School (28) in the Division of Sultan Kudarat S.Y 2015-2016.

TABLE 1

Distribution of respondents according to school

\begin{tabular}{lcc}
\hline \hline Name of School & Population & No. of Respondents \\
Esperanza CS & 46 & 32 \\
Kalawag CS & 79 & 56 \\
Tamnag CS & 40 & 28 \\
\hline Total & 165 & 116 \\
\hline \hline
\end{tabular}

RESULTS

Teachers have high soft skills proficiency level:

TABLE 2

Teachers' soft skills proficiency level

\begin{tabular}{lll}
\hline \hline Soft Skills of Teachers & Mean & Description \\
\hline Communication Skills & 3.99 & High \\
Critical Thinking Skills & 3.95 & High \\
Teamwork & 4.37 & High \\
Ethics & 4.08 & High \\
Leadership Skills & 4.03 & High \\
Overall Mean & 4.08 & High \\
\hline \hline
\end{tabular}


This study utilized the stratified random sampling. The researcher used the Lwangga and Stanley (1991) formula to determine the sample size of the survey. Table 1 shows the distribution of respondents' total population and the sampled number of respondents by school.

Teachers' proficiency level was high in communication skills $(M=3.99)$ such as in providing motivation to others $(\mathrm{M}=4.10)$, relating to people of diverse backgrounds $(\mathrm{M}=$ 4.08) and practicing an active listening skill and teaching essential skills $(M=4.05)$. Nevertheless, expanding communicative skill obtained the lowest mean of 3.90.

In critical thinking skills, the teachers were high in withstanding and giving full responsibility $(M=4.08)$, suspending judgment until all facts have been gathered $(M=4.02)$ and making a conclusion based on valid proof $(M=3.99)$. However, identifying and analyzing problems in difficult situations yielded the lowest mean of 3.83. The mean of 3.95 indicated that teachers were high in critical thinking skills.

Moreover, in teamwork, the teachers were very high in: showing respect for other coworkers ( $M=4.55)$ and recognizing and respecting other's attitude, behavior and beliefs $(\mathrm{M}=4.51)$. It also reveals that they were high in: considering a suggestion from others $(\mathrm{M}=4.49)$, helping someone on the team $(\mathrm{M}=4.44)$ and doing fair share of the work $(\mathrm{M}=$ 4.39). On the other hand, arriving on time for nearly all meetings got the lowest mean of 4.20. The mean of 4.37 described that teachers' teamwork was high.

Furthermore, in ethics, the teachers were high in all skills such as being concerned about the well-being of partners ( $M=4.18)$, understanding the economy crisis, environment, and social, cultural aspects professionally ( $\mathrm{M}=4.14)$ and noticing if someone is offended $(M=4.11)$. Nevertheless, expressing different feelings to other people obtained the lowest mean of 3.95. The mean of 4.08 described that the ethics of the teachers were high.

Finally, teachers' proficiency was high in leadership skills such as being sensitive to individual differences $(M=4.33)$, experimenting and learning from failures $(M=4.26)$ and improving group performance through the use of creative process $(M=4.05)$. However, constructing new knowledge of the basic theories of leadership got the lowest mean of 3.89. The mean of 4.03 indicated that teachers have high leadership skills.

To conclude, the overall mean of 4.08 signifies that the teachers have high soft skills proficiency.

TABLE 3

School performance of selected schools in Sultan Kudarat

\begin{tabular}{llll}
\hline \multicolumn{3}{c}{ National Achievement Rate } \\
\hline School & $2012-2013$ & $2013-2014$ & $2014-2015$ \\
\hline Esperanza CS & $66.92 \%$ & $65.39 \%$ & $74.47 \%$ \\
Kalawag CS & $64.53 \%$ & $68.37 \%$ & $85.29 \%$ \\
Tamnag CS & $66.84 \%$ & $74.42 \%$ & $76.57 \%$ \\
\hline & & Drop-out Rate & $0.2 \%$ \\
\hline Esperanza CS & $0.1 \%$ & $0.2 \%$ & $0 \%$ \\
Kalawag CS & $0 \%$ & $0 \%$ & $0 \%$ \\
Tamnag CS & $0 \%$ & $0 \%$ & $92 \%$ \\
\hline & & Completion Rate & $82.94 \%$ \\
\hline Esperanza CS & $100 \%$ & $96 \%$ & $89 \%$ \\
Kalawag CS & $87.01 \%$ & $92.93 \%$ & \\
\hline \hline
\end{tabular}


These results imply that teachers were efficient in integrating soft skills in performing their roles and functions in the school. Schools have different levels of performance in three (3) consecutive years:

The three schools all showed an increasing rate for three years in the National Achievement Rate. Kalawag Central School got the highest rating of $85.29 \%$ for the school year 2014-2015. On the other hand, Kalawag Central School also obtained the lowest rating of 64.53\% for the school year 2012-2013. The data also revealed that the three schools obtained their highest ratings of National Achievement Test for the school year 2014-2015.

In Drop-out rate, both Kalawag Central School and Tamnag Central School attained the best performance of zero drop-out rates for three consecutive school years. These schools strongly implement practices such as home-visitation programs, feeding programs, parentteacher conferences and build a partnership with stakeholders to maintain and support these levels of performance. However, Esperanza Central School showed a decreasing performance in drop-out rate for three consecutive years. The school also obtained the lowest performance of $0.2 \%$ for the Academic years 2013-2014 and 2014-2015.

Finally, the three schools have different levels of performance in Completion Rate for three years. Esperanza Central School got the highest rating of $100 \%$ for the school year 2012-2013. However, the school's performance decreased for the last two school years. On the contrary, Tamnag Central School started with the lowest rating of $38.01 \%$ for the school year 2012-2013 and reached its highest rating of 89\% for the school year 2014-2015. Meanwhile, Kalawag Central School obtained its highest performance of $92.93 \%$ for the school year 2013-2014. The results imply that school performance varies, thus the roles of the teachers are significant to increase the performance of the school. Outcomes also entail that other factors also affect school performance aside from teachers' soft skills proficiency.

Teachers' soft skills proficiency level in communication and ethics significantly affects the school performance:

TABLE 4

Relationship between soft skills proficiency level of teachers and their school's performance in the national achievement rate

\begin{tabular}{lllll}
\hline \hline & Soft Skills & & Extent of Relationships & \\
\hline & Beta & t-value & p-value & Remarks \\
\hline Communication Skills & 0.578 & 2.786 & 0.006 & Significant \\
Critical Thinking & -0.025 & -0.135 & 0.893 & Not Significant \\
Teamwork & 0.306 & 1.707 & 0.091 & Not Significant \\
Ethics & -0.542 & -2.671 & 0.009 & Significant \\
Leadership Skills & -0.186 & -0.752 & 0.454 & Not Significant \\
\hline
\end{tabular}

Multiple R: .376

R-squared: .141 Sig F: .009

F-value: 3.289

The study found that there is a significant relationship between the National Achievement Rate and soft skills proficiency level of the teachers. This is supported by an F-value of 3.289 with significant $F$ of .009. A p-value of less than .05 leads to the rejection of the hypothesis of no relationship. The result also indicates that National Achievement Rate and teachers' soft skills are related to each other. The multiple $\mathrm{R}$ value of .376 indicates that there is an increase in the National Achievement rate of .376 when teachers are pro- 
ficient in their soft skills. The R-squared of .141 implies that $14.1 \%$ of the variation in National Achievement Rate was due to the five soft skills of the teachers. Further, among the five soft skills of the teachers, communication skills and ethics showed a significant relationship with the National Achievement rate. Critical thinking, teamwork, and leadership skills influence the National Achievement rate but were not significant. The result also revealed that there is an inverse relationship between ethics and National Achievement rate. This implies that when teachers have poor ethics, National Achievement rate will likely increase. Based on the interview conducted, teachers sometimes expressed emotions to gain the attention of the learners without considering its impact. This approach helps the teachers maintain the focus of the learners during the teaching-learning process. Also, good communication skills positively influence the National Achievement rate.

TABLE 5

Relationship between soft skills proficiency level of teachers and the school's drop-out rate

\begin{tabular}{lllll}
\hline \hline & Soft Skills & Extent of Relationships & & \\
\hline & Beta & t-value & p-value & Remarks \\
\hline Communication Skills & -0.574 & -2.819 & 0.006 & Significant \\
Critical Thinking & 0.033 & 0.175 & 0.861 & Not Significant \\
Team work & -0.314 & -1.755 & 0.082 & Not Significant \\
Ethics & 0.544 & 2.686 & 0.008 & Significant \\
Leadership Skills & 0.182 & 0.738 & 0.463 & Not Significant \\
\hline Multiple R: .380 & & & & \\
R-squared: .144 & Sig F: .007 & & & \\
F-value: 3.374 & & & & \\
\hline \hline
\end{tabular}

Further, results showed that there is a significant relationship between the drop-out rate and soft skills proficiency level of the teachers in Sultan Kudarat. An F-value of 3.374 with significant $\mathrm{F}$ of .007 indicates that the correlation between the two variables is significant. These outcomes reveal that soft skills of teachers and drop-out rate were related to each other. The multiple $\mathrm{R}$ value of .380 indicates that drop-out rate of the school will decrease to .380 when teachers are proficient in their soft skills. The coefficient variation of R-squared of .144 implies that $14.4 \%$ of the variation in drop-out rate was due to the five soft skills of the teachers.

TABLE 6

Relationship between soft skills proficiency level of teachers and the school's completion rate

\begin{tabular}{lllll}
\hline \hline & Soft Skills & Extent of Relationships & & \\
\hline & Beta & t-value & p-value & Remarks \\
\hline Communication Skills & -0.424 & -2.008 & 0.047 & Significant \\
Critical Thinking & 0.170 & 0.891 & 0.375 & Not Significant \\
Teamwork & -0.330 & -1.810 & 0.073 & Not Significant \\
Ethics & 0.327 & 1.584 & 0.116 & Not Significant \\
Leadership Skills & 0.017 & 0.680 & 0.946 & Not Significant \\
\hline \hline
\end{tabular}

Multiple R: .332

R-squared: $.110 \quad$ Sig F: .037

F-value: 2.479 
Critical thinking, teamwork, and leadership skills influence the drop-out rate but were not significant. Meanwhile, ethics have a positive relationship with the school's drop-out rate. This implies that the drop-out rate decreases if the ethics of the teachers are high. Also, poor communication skills lead to an increased drop-out rate.

Finally, findings of the study revealed that there is a significant relationship between teachers' soft skills proficiency level and the completion rate as evident from the F-value of 2.479 with significant $F$ of .037. This also indicated that completion rate of the school was affected by the soft skills proficiency level of the teachers.

The multiple R-value of .332 indicates that there is an increase in completion rate of .332 when teachers are proficient in the five soft skills. The coefficient variation or Rsquared of 110 implies that $11 \%$ of the variation completion rate was due to the soft skills of the teachers. Among the five soft skills of the teachers, only communication skills show a significant inverse relationship with the schools' completion rate. It implies that when teachers have negative communication skills, completion rate will likely increase. This outcome was supported by the interview conducted that teachers sometimes used negative reinforcements to prevent pupils from leaving the school. Negative reinforcements become one of the ways to motivate learners to complete the educational levels.

The remaining soft skills such as critical thinking skills, teamwork, ethics, and leadership skills affect the completion rate but are not significant. This implies that the completion rate of the school increases when the teachers are highly proficient in their communication skills. The $11 \%$ variation showed that there are many factors which influence the school's completion rate aside from the soft skills of the teachers. This result agrees with the responses from the interview conducted by the researcher that teachers perceived other factors like: poor academic performance, school environment, lack of parental support, socio-economic status and bullying that influence the school's completion rate.

\section{DISCUSSION}

This paper reports teachers' soft skills proficiency level and the extent of school performance. It also provided discussions about the relationship of teachers' soft skills proficiency and school performance of selected school. Teachers are facing various modifications and responsibilities in the society. Thus, it is important for the teachers to possess soft skills to achieve success and cope with the changes in the organization (Lee and TienTse, 2011). Teachers valued soft skills and believed that it is significant in the workplace. This view reinforced the findings that teachers are apparently proficient in their soft skills. They have high communication skills, critical-thinking, teamwork, ethics and leadership skills. This implied that they were efficient and effective despite the complexity of the job. It conforms to existing research finding that soft skills help the teachers perform their functions successfully amidst the job difficulty (Ngang et al., 2015).

School performance evaluations include different indicators to assess the achievement of the school (Sarrico et al., 2012). In the Philippines, the Department of Education used the National Achievement rate, enrollment rate, drop-out rate, cohort survival rate, completion rate and repetition rate as variables of school performance (Maligalig et al., 2010). Documentary analysis showed that the schools have variations in their performance for three (3) years. They conducted different intervention programs to increase their level of performance and viewed teachers as strong determinants of school performance. These accord with the study of Maligalig et al. (2010) that schools formulate and implement various programs to stop the declining of key indicators for school performance. The integration of soft skills is essential for the organization to prosper and continuously achieve its 
goals (Jamison, 2010). This study showed that soft skills proficiency level of the teachers significantly influences the school performance regarding the National Achievement rate, drop-out rate, and completion rate. Specifically, communication skills and ethics showed significance in three (3) indicators. Toyama (2014) agreed that communication skills help teachers support the well-being of the learners, especially students who are prone to leaving the school. The result of the study also conformed to Ngang et al. (2015) that ethics play a crucial role in creating a strong rapport between teachers and students which promotes the development of the learners through improved academic skills and diminished behavioral problems.

The variations in school performance were not isolated to a single factor (Breier, 2010). In this study, the degree of variation proves that other factors also affect school performance aside from the soft skills of the teachers. Teachers mentioned other factors like parental support, academic performance, school environment, bullying and economic status as predictors of school performance. The findings of this study suggest a need for teachers to upgrade continuously and integrate soft skills into the workplace. Alongside this, however, is the need to identify and address other factors that prevent the school from achieving its goals.

\section{CONCLUSION}

In conclusion, this study has shown that soft skills proficiency is one of the qualities that a teacher should have. The high soft skills proficiency level of the teachers meant that they are efficient in performing their roles and functions to enhance the school performance. The Division of Sultan Kudarat is recommended to share the programs of the schools with teachers who have high soft skills proficiency level. In this, other teachers can improve their soft skills proficiency level and contribute to improving the school performance. Also, schools have different levels of performance in National Achievement rate, drop-out rate and completion rate for three years. These rates allow the school to monitor their performance to determine the indicators that must be given more attention and implement intervention programs to increase their school performance. Teachers as strong determinants of school performance develop and implement programs for the welfare of the learners and the school.

The significant relationship between teachers' soft skills proficiency level and school performance indicates that teachers should always be proficient in their soft skills to enhance school performance. Soft skills proficiency level of the teachers helps them create a healthy working environment and efficient classroom instruction. They will be more effective in improving the academic achievement of the students and intervening to some behavioral problems that prevent learners from completing all levels of education. Similarly, identifying other factors that influence school performance would be beneficial to the school.

\section{LIMITATIONS AND RECOMMENDATIONS}

This study has some limitations and the findings must be used with caution. This study used survey to assess the soft skills of students. However, a mixed method using observations and questionnaires would give more refined findings. Thus, authors must use mixedmethod design in future and get better findings. Other indicators of teachers effectiveness and better performance should also be considered in future research. 


\section{REFERENCES}

Abd Hamid, Siti Rafiah, Sharifah Sariah SH., and Nik Ahmad Hisham Ismail. 2012. Teaching quality and performance among experienced teachers in Malaysia. Australian Journal of Teacher Education 37, no. 5: 85-103.

Adeyemi, Babatunde. 2010. Teacher-related factors as correlates of pupils' achievement in social studies in Southwestern Nigeria. Electronic Journal of Research in Educational Psychology 8, no. 1: 313-332.

Amini, Mitra, Najafipour S, Torkan N, and Ebrahiminejad, F. 2010. Correlation between educational performance and com- $\quad$ munication skills of Jahrom medical teachers. Journal of Babol University of Medical Sciences (JBUMS) 12, no. 1: $100-105$. Balcar, Jiří. 2014. Soft skills and their wage returns: Overview of empirical literature. Review of Economic Perspectives 14, no. 1: 3-15. DOI: 10.2478/revecp-2014-0001

Birjandi, Parviz, and Marzieh Bagherkazemi. 2010. The relationship between Iranian EFL teachers' critical thinking ability and their professional success. English Language Teaching 3, no. 2: 135-145. D0I: 10.5539/elt.v3n2p135

Bhatnagar, Nitin. 2011. Effective communication and soft skills. New Delhi, IN: Pearson Education India.

Denham, Susanne A., Hideko H. Bassett, and Katherine Zinsser. 2013. Early childhood teachers as socializers of young children's emotional competence. Early Childhood Education Journal 40, no. 3: 137-143.

Boon, Helen. 2011. Raising the bar: Ethics education for quality teachers. Australian Journal of Teacher Education 36, no. 7: 76-93.

Breier, Mignonne. 2010. From 'financial considerations' to 'poverty': Towards a reconceptualization of the role of finances in higher education student drop out. Higher Education 60, no. 6: 657-670.

Chapman, Chris, Jennifer Laird, Nicole Ifill, and Angelina KewalRamani. 2011. Trends in high school dropout and complerates in the United States: 1972-2009. National Center for Education Statistics, Jessup, MD.

Conrad, David, and Robert Newberry. 2011. 24 Business communication skills: Attitudes of human resource managers versus business educators. American Communication Journal 13, no. 1: 4-23.

Crutchfield, Tammy N., and Kimberly Klamon. 2014. Assessing the dimensions and outcomes of an effective teammate. Journal of Education for Business 89, no. 6: 285-291.

Dede, Chris. 2010. Comparing frameworks for 21st century skills. 21st century skills: Rethinking how students learn. Bloomington, IN: Solution Tree Press.

Deepa, Seth, and Manisha Seth. 2013. Do soft skills matter? Implications for educators based on recruiters' perspective. IUP Journal of Soft Skills 7, no. 1: 7-20.

DiPrete, Thomas A., and Jennifer L. Jennings. 2012. Social and behavioral skills and the gender gap in early educational achievement. Social Science Research 41, no. 1: 1-15. DOI: 10.1016/j.ssresearch.2011.09.001

Dixon, Jami, Cody Belnap, Chad Albrecht, and Konrad Lee. 2010. The importance of soft skills. Corporate Finance Review 14, no. 6: 35-38. DOI: 10.1016/j.jdeveco.2012.06.002

Farmer, Thomas W., Meghan McAuliffe L, and Jill V. Hamm. 2011. Revealing the invisible hand: The role of teachers in chil- $\quad$ dren's peer experiences. Journal of Applied Developmental Psychology 32, no. 5: 247-256.

Ghaemi, Hamed, and Reza Taherian. 2011. The role of critical thinking in EFL teachers' teaching success. MJAL 3, no. 1: 8-22.

Gould, Rebecca A., and Deborah D. Canter. 2012. Management matters. Journal of the Academy of Nutrition and Dietetics 112, no. 5: S38-S40.

Hallinger, Philip, and Ronald H. Heck. 2010. Collaborative leadership and school improvement: Understanding the impact on school capacity and student learning. School Leadership and Management 30, no. 2: 95-110.

Harn, Payling. 2015. The exploratory study on the relationships among Taiwanese college students construallevel, gratitude and intimate attachment. International Journal of Humanities, Arts and Social Sciences 1, no. 1: 1-5. DoI: 10.20469/ijhss.20001

Harris, Roger, Michele Simons, Doug Hill, Erica Smith, Ron Pearce, John Blakeley, Sarojni Choy, and David Snewin. 2001. The changing role of staff development for teachers and trainers in vocational education and training. National Centre for Vocational Education Research, Leabrook, AU. 
Hart, Stuart L., and Mark B. Milstein. 2003. Creating sustainable value. The Academy of Management Executive 17, no. 2: 56-67.

Helterbran, Valeri R. 2010. Teacher leadership: Overcoming'I am just a teachers' syndrome. Education 131, no. 2: 363-371. Hulpia, Hester, and Geert Devos. 2010. How distributed leadership can make a difference in teachers' organizational com- mitment? A qualitative study. Teaching and Teacher Education 26, no. 3: 565-575.

Jackson, Shirley A., and Fred C. Lunenburg. 2010. School performance indicators, accountability ratings, and student achieve- ment. American Secondary Education 39, no. 1: 27-44.

Jacolbia, Rovelina B. 2015. Gender equality learning materials methods and strategies subject matter evaluation. Journal of Advances in Humanities and Social Sciences 1, no. 1: 9-18. DOI: 10.20474/jahss-1.1.2

James, Rajani. 2015. Evaluation of critical thinking in higher education in Oman. International Journal of Higher Education 4, no. 3: 33-43.

Jamison, David. 2010. Leadership and professional development: An integral part of the business curriculum. Business Education Innovation Journal 2, no. 2, 102-111.

Kane, Thomas J., Eric S. Taylor., John H. Tyler, and Amy L. Wooten. 2011. Identifying effective classroom practices using student achievement data. Journal of Human Resources 46, no. 3: 587-613. DOI: 10.3368/jhr. 46.3.587

Kano, Erasto. 2012. Leadership styles and school performance. URL: goo.gl/2FZpO0

Keller, Melanie M., Thomas Goetza, Eva S. Beckera, Vinzenz Morgerb and Lauren Hensley. 2014. Feeling and showing: A new conceptualization of dispositional teacher enthusiasm and its relation to students' interest. Learning and Instruc-

33: 29-38. DOI: 10.1016/j.learninstruc.2014.03.001

Khasawneh, Samer, Aieman Omari, and Abdullah M. Abu-Tineh. 2012. The relationship between transformational leader- ship and organizational commitment: The case for vocational teachers in Jordan. Educational Management Adminis- tration \& Leadership 40, no. 4: 494-508. DOI: 10.1177/1741143212438217

Kim, Tae-Yeol, and Minsoo Kim. 2013. Leaders' moral competence and employee outcomes: The effects of psychological empowerment and person-supervisor fit. Journal of Business Ethics 112, no. 1: 155-166.

Koonmee, Koonmeea, Anusorn Singhapakdib, Busaya Virakula, and Dong-Jin Lee .2010. Ethics institutionalization, quality of work life, and employee job-related outcomes: A survey of human resource managers in Thailand. Journal of Business Research 63, no. 1: 20-26.

Kunter, Mareike, Uta Klusmann, Jürgen Baumert, Dirk Richter, and Thamar Voss. 2013. Professional competence of teachers: Ef-fects on instructional quality and student development. Journal of Educational Psychology 105, no. 3: 805-820. DOI: $10.1016 /$ j.jbusres.2009.01.006

Kuusisto, Elina, Kirsi Tirri, and Inkeri Rissanen. 2012. Finnish teachers' ethical sensitivity. Education Research InternaDOI: $10.1155 / 2012 / 351879$

Kythreotis, Andreas, Petros Pashiardis, and Leonidas Kyriakides. 2010. The influence of school leadership styles and culture on students' achievement in Cyprus primary schools. Journal of Educational Administration 48, no. 2: 218-240. DOI: $10.1108 / 09578231011027860$

Lai, Emily R. 2011. Critical thinking: A literature review. Pearson's Research Reports 6, 40-41.

Langlois, Lyse, and Claire Lapointe. 2010. Can ethics be learned? Results from a three-year action-research project. Journal of Educational Administration 48, no. 2: 147-163. DOI: 10.1108/09578231011027824

Lee, Li-Tze, and Tien-Tse Lee. 2011. Investigating soft skills for success in the workforce: Perceptions of elementary school teachers. International Review of Social Sciences and Humanities 1, no. 2: 140-149.

Lingard, Robert W. 2010. Improving the teaching of teamwork skills in engineering and computer science. Journal of Sys- temics, Cybernetics, and Informatics 8, no. 6: 20-23.

Liu, Huimin, and Xiaofeng Dong. 2016. Influence of social relations on knowledge conflicts-An empirical study from Chinese universities. Journal of Administrative and Business Studies 2, no. 1: 8-18. D0I: 10.20474/jabs-2.2.2

Ludlow, Barbara. 2011. Teacher leadership: Why teachers must be leaders. Teaching Exceptional Children 43, no. 5: 6. Lwanga, Stephen K., and Stanley Lemeshow. 1991. Sample size determination in health studies. World Health Organization, Geneva, $\mathrm{CH}$. 
Main, Katherine. 2010. Teamwork-Teach me, teach me not: A case study of three Australian preservice teachers. The Aus- $\quad$ tralian Educational Researcher 37, no. 3: 77-93. D0I: 10.1007/BF03216931

Majid, Norliza A., Zalizan Mohd. J, and Norzaini Azman, and Saemah Rahman. 2010. Communication skills and work moti- $\quad$ vation amongst expert teachers. Procedia-Social and Behavioral Sciences 7: 565-567.

DOI: $10.1016 /$ j.sbspro.2010.10.075

Majid, Shaheen, Zhang Liming, Shen Tong, and Siti Raihana. 2012. Importance of soft skills for education and career success.

International Journal for Cross-Disciplinary Subjects in Education 2, no. 2: 1037-1042.

DOI: $10.20533 /$ ijcdse.2042.6364.2012.0147

Maldonado-Carreño, Carolina, and Elizabeth Votruba-Drzal. 2011. Teacher-child relationships and the development of academic and behavioral skills during elementary school: A within-and between-child analysis. Child Development 82, no. 2: 601-616.

Maligalig, Dalisay S., Rhona B. Caoli-Rodriguez, Arturo M. Jr, and Sining Cuevas. 2010. Education outcomes in the Philip- pines. ADB Economics Working Paper no. 199, Asian Development Bank. Manila, PH.

Marcial, Dave E. 2012. Investigating soft skills among information technology managers in higher education insti- $\quad$ tutions in the Philippines. Paper presented at the 5th International Conference of Education, Research and Innovation,

Madrid, ES, November 19-21.

Marques, Joan. 2013. Understanding the strength of gentleness: soft-skilled leadership on the rise. Journal of Business

Ethics 116, no. 1: 163-171. DOI: 10.1007/s10551-012-1471-7

Metzler, Johannes, and Ludger Woessmann. 2012. The impact of teacher subject knowledge on student achievement: Evi- $\quad$ dence from within-teacher within-student variation. Journal of Development Economics 99, no. 2: 486-496.

Migosi, Joash A., Daniel Nanok, Charles N. Ombuki, and Joseph Metet. 2012. Trends in primary school dropout and comtion rates in the pastoralist Turkana County, Kenya. Universal Journal of Education and General Studies 1, no. 10:

331-338.

Narvaez, Darcia. 2001. Ethical sensitivity. Activity booklet. URL: https://goo.gl/IvtFk9 (accessed January 14, 2017).

Ngang, Ngang, Tang Keow, and Tan Chan C. 2015. The importance of ethics, moral and professional skills of novice teachers.

Procedia-Social and Behavioral Sciences 205: 8-12. DOI: 10.1016/j.sbspro.2015.09.004

Noddings, Nel. 2012. The caring relation in teaching. Oxford Review of Education 38, no. 6: 771-781.

DOI: $10.1080 / 03054985.2012 .745047$

Ouko, Ongang H. 2015. Determinants of standard one Pupils' achievement in literacy and numeracy in Gucha District, Kisii County Kenya. Doctoral dissertation, Kenyatta University, Nairobi, Kenya.

Pandiello, Suárez, Javier, Marián García V., and Manuel A. Muñiz. 2016. The Determinants of Non-cognitive education: Does the school matter? Empirical evidence from Spain. European Journal of Education 51, no. 3: 408-424.

Prasad, Suraj, and Hien Tran. 2013. Work practices, incentives for skills, and training. Labour Economics 23: 66-76.

Prasad, Suraj, and Hien Tran. 2011. Promotions, Multiskilling and Incentives for Skills. Working Paper, University of New South Wales, New South Wales, AU. DOI: 10.1016/j.labeco.2013.03.003

Puccio, Gerard J., Marie Mance, and Mary C. Murdock. 2010. Creative leadership: Skills that drive change. Buffalo, NY: Sage Publications.

Rao, M. S. 2010. Soft skills: Enhancing employability: Connecting campus with corporate. New Delhi, IN: IK International Pvt Ltd.

Robles, Marcel M. 2012. Executive perceptions of the top 10 soft skills needed in today's workplace. Business Communica-

Quarterly 75, no. 4: 453-465. DOI: $10.1177 / 1080569912460400$

Romano, Elisa, Lyzon Babchishin, Linda S. Pagani, and Dafna Kohen. 2010. School readiness and later achievement: Repli- $\quad$ cation and extension using a nationwide Canadian survey. Developmental Psychology 46, no. 5: 995-1007.

DOI: $10.1037 / \mathrm{a} 0018880$

Sabates, Ricardo, Kwame Akyeampong, Jo Westbrook, and Frances Hunt. 2011. School dropout: Patterns, causes, changes and policies. Centre for International Education, School of Education and Social Work, University of Sussex, Brighton, UK.

Saifi, Saifullah, and Ta riq Mehmood. 2011. Effects of socioeconomic status on students achievement. International Journal 
of Social Sciences and Education 1, no. 2: 119-128.

Sarrico, Cláudia S., Maria J. Rosa, and Maria J. Manatos. 2012. School performance management practices and school achievement. International Journal of Productivity and Performance Management 61, no. 3: 272-289.

Seashore Louis, Karen, Beverly Dretzke, and Kyla Wahlstrom. 2010. How does leadership affect student achievement?

Re- $\quad$ sults from a national US survey. School Effectiveness and School Improvement 21, no. 3: 315-336.

DOI: $10.1080 / 09243453.2010 .486586$

Shapira-Lishchinsky, Orly. 2011. Teachers' critical incidents: Ethical dilemmas in teaching practice. Teaching and Teacher Education 27, no. 3: 648-656. DOI: 10.1016/j.tate.2010.11.003

Strike, Jonas SK. 2015. The ethics of teaching. Washington DC, WA: Teachers College Press.

Strom, Paris S., and Robert D. Strom. 2011. Teamwork skills assessment for cooperative learning. Educational Research and Evaluation 17, no. 4: 233-251. D0I: 10.1080/13803611.2011.620345

Tang, Keow N., Wallapha Ariratana, and Saowanee Treputharan. 2013. Perceived leadership soft skills and trustworthiness of deans in three Malaysian public universities. Educational Research for Policy and Practice 12, no. 3: 211-224.

DOI: $10.1007 / \mathrm{s} 10671-013-9142-8$

Tarmuchi, Nor Rashimahwati, Haslinda Mohamed, Saidatul Akmar I. 2015. Asynchronous learning tools use in graduate study: A preliminary survey. International Journal of Humanities, Arts and Social Sciences 1, no. 1: 13-18.

DOI: 10.20469 /ijhss.20003

Taylor J, Roehrig AD, Hensler BS, Connor CM, and Schatschneider C. 2010. Teacher quality moderates the genetic effects on early reading. Science 328, no. 5977: 512-514. DoI: 10.1126/science.1186149

Toyama, Narumi. 2014. Japanese senior high school teachers' perceptions of the role of teachers in promoting the emo- tional well-being of their students. Master's thesis, University of Wollongong, New South Wales, AU.

Training, MTD. 2012. Effective communication skills. London, UK: MTD Training \& Ventus Publishing APS.

Ward, Valerie G., and Dorothy I. Riddle. 2014. Weaving soft skills development into everyday employment services in Canada. URL: goo.gl/sPMXcq (accessed January 14, 2017).

Ya mauchi, Futoshi, and Yanyan Liu. 2011. Impacts of an early education intervention on students' learning achievement. International Food Policy Research Institute, Washington, DC, WA.

Yi, Ling, Zhi-Ta o Lianga, Yong Pengb, Xia Yaoc, Hu-Biao Chena, and Zhong-Zhen Zhaoa. 2012. Tissue-specific metabolite profiling of alkaloids in Sinomenii Caulis using laser microdissection and liquid chromatography-quadrupole/time of flight-mass spectrometry. Journal of Chromatography A 1248: 93-103.

- This article does not have any appendix. - 